\title{
Perspectives for More Inclusive and Impactful Fair Trade. Analysis of the Handloom Industry in Nepal
}

\author{
Karolina Osterczuk*
}

\begin{abstract}
Summary
Fair trade movement is keeping evolving and developing new, more impactful practices, dedicated to multi-faceted support of producers and protection of natural environment. Hand looming is a disappearing craft of a high cultural value and a traditional profession providing income to a significant amount of people from the global south. The industry relies on a support of local non-profit organizations, the same as the artisans who hand wave. The article explores the possibilities for international, fair collaboration within the global community of conscious fashion and sustainable design, which benefits both sides: the craftsmen and the designers.
\end{abstract}

Keywords: fair trade, social innovation, craftsmanship, sustainable design

JEL: Q01, F16, M14, O15

\section{INTRODUCTION}

The fair trade movement was established in the 1960s and strengthened in the 70s. Its aim was to ensure fair salaries and decent working conditions for discriminated producers and farmers from developing countries. By the definition, it is a "commercial network of production-distributionconsumption oriented towards interdependent, sustainable development" (Audebrand \& Pauchant, 2009). Fair trade is a component of "the new forces of market construction, coordination and regulation, which link social movements, commodities and policies in new global networks". It is the most dynamic, market-based practice to create social change and to transform globalization into a fair model. More advanced initiatives from the fair trade movement are aimed at multi-faceted support, providing decent income, skills training, education and new effective and ecologically friendly technologies. A meaningful difference is the basic assumption, that smallholders can become leaders of their community and support it towards a sustainable development. Empowerment is practiced for example by the coffee trader Bean Voyage, which declares that "trade is not just an exchange of goods (...), but the investment in holistic sustainability of the people and planet" (https:// beanvoyage.com/pages/about). So called "care trade" is an expanding idea of changing the existing trade system and another form of social enterprise with an international range. As a third party in the fair and care trade movement, they service a large group of consumers, who pay attention to the origin of purchased goods and consider themselves conscious buyers. Even though the mainstream economy convinces us that consumers seek the lowest possible prices and the maximization of individual gains, the image of a consumer has been changing from an egocentric profit maker, to a person who is aware of consumption's cost and actively "votes with his money" by choosing ethically made, eco-friendly products; even for a higher price. Conscious fashion and sustainable design are concepts which have gained a lot of popularity and become movements followed by responsible consumers. Transforming globalization provides new possibilities of development for a disadvantaged global south. Said possibilities are based on a commercial exchange and economic inclusion, not a charity or financial aid.

Faculty of Management, University of Warsaw, Poland, https://orcid.org/0000-0003-2189-3170, e-mail: karolina.osterczuk@gmail.com 
Hand crafted fabric is a very unique product on today's market, which makes it an attractive exported good, produced by small workshops and craftsmen. At the same time, it provides a source of income to a significant amount of people from the global south and has been an economical trampoline to discriminated members of society like women and low castes. The responsible textiles value chain is an object of research and interest for NGOs and experts, because of its impact on rural development. It has a strong potential for advanced fair trade initiatives to bring change and offer to the market a desired product. Fashion enterprises, like Mayamiko, build their core marketing strategy around the origin of their products, which allows them to create a responsible image.

Insights provided by the theory of transformative globalization suggests the collaborative model of development, through fair trade and empowerment of local organizations and open access to modern technologies. This leads to independent and sustainable growth. Social innovation is understood as "the development and delivery of new ideas and solutions (products, services, models, modes of provision, processes) at different socio-structural levels that intentionally seek to change power relations and improve human capabilities, as well as the processes via which these solutions are carried out" (Chiappero-Martinetti, Ziegler \& Budd, 2017). According to researchers, only a participatory initiative creates social change, not a temporary action, which is not continued after the foreign actor's disappearance (Chandra, 2018). Involvement of local leaders and organizations is crucial for any initiative aspiring to create a positive impact. The Nepali non-profit sector is very well developed, supports society on many levels, as well the craftsmanship and producers of handmade fabrics and textiles. It holds important insights about handcrafted goods and the industry, while also acting as a safety bumper between producers and the market. It protects members of the value chain from exploitation and supports their development (Adhikari, Shrestha, Dorji, Lemke, \& Subedee, 2018).

The Indian NGO, Dastkar, declared themselves to "strongly believe in craft as a social, cultural and economic force, that despite being marginalized due to urbanization and industrialization, has enormous strength and potential and has thus a vital role to play within the economic mainstream of the country" (Adhikari, Shrestha, Dorji, Lemke, \& Subedee, 2018). Craft skills are passed down from generation to generation. Craftsmanship is strongly rooted in local culture, while traditional professions create authenticity of the society and support its perception of identity. According to the UNCTAD handbook for artisans from developing economies, a very important issue is whether they can adapt their products to meet the requirements of the global markets or not, because the purchasing power of local markets is too limited to support them (International Trade Centre, 1991). At the same time the 'handmade' label in western countries is actually having its renaissance. In the opposite of machine produced and all equal goods, those created by humans are considered to have a touch of soul and uniqueness of imperfection.

One of the ways to raise competitiveness of local products is to improve its design - in both, an aesthetical as well as a practical meaning. Collaborations between the designer and the craftsman and a combination of modern design with traditional craft can be a source of innovation and skills training. Product development is considered to be one of the strategies for scaling the impact of social enterprise in a developing economy (Bocken, Fil, Prabhu, 2016). In order to maintain financial sustainability and to bring change to the community, SE must keep on adapting to market requirements. There are potential threats in such dynamic, trend sensitive industries like fashion and design, to which textiles producers are directly dependent. The important factor however is the responsible approach to the project. As Victor Papanek emphasized already over 30 years ago, the object of design will carry with it the moral, social and environmental consequences. Design is a multifaceted process that goes far beyond aesthetics.

Having the above in mind, a cognitive excursion to a textile craft in Nepal was planned and took place with a group of six people, including students and academics of industrial design 
and management. The aim was to recognize opportunities and threats, which design and production of textiles goods can carry, as well to get familiar with the cultural context of it.

The following article analyzes the collected information and supplements it with a literature review in order to search for opportunities of more impactful and inclusive fair trade with textile craftsmanship. It has been suggested by researchers that it represents a social innovative approach due to its developmental application.

\section{RESEARCH METHOD}

The article is based on the field observations and informal interviews, made during the cognitive excursion to Nepal, as well on existing literature related to craftsmanship's developmental role and social innovation theory. The local textiles industry was analyzed through the perspective of a stakeholder map and value chain. An explorative journey program involved visiting places and meeting actors engaged at various levels of handmade textiles production, as well those indirectly affecting the industry. The whole process of fabric production was acknowledged - from harvesting plants, to final product sewing. Identifying human and institutional resources contributed to a better understanding of the craftsmen community (Starnawska, 2016). Research and excursion were dominated by a human center approach. Various intellectual tools were engaged - design thinking, ideation and brainstorming - in order to synthesize information and compare the current observations of participants. A photographic documentation and journey map in a smartphone application served as a systematization of collected data.

\section{INDUSTRY AND THE STAKEHOLDERS}

After tourism, the textile and carpet industry is the biggest sector of the Nepali economy, offering a source of employment and income of households. According to WITS, in 2015 over 43\% of exported textiles were sold to India, and over $19 \%$ to the United States. The goods are mostly handcrafted, produced by small business or house workshops. Woven on handlooms and decorated by hand block printing or embroidery. Very typical fabrics are hemp, cotton and nettle, as well wool, pashmina and Dhaka (WITS, 2015).

The garment industry is the second largest item of export in Nepal after the woolen carpet. It earned one-third of the total export income, and directly employed 90,000 people, supporting the livelihood of 450,000 persons (Sapkota, 2010). The industry benefited from the Multi-Fiber Arrangement (MFA), but the quota has ended in 2004, causing a significant downfall in export (Fair Wear Foudation, 2013). The developmental objective in Nepal, according to a UN report, is to improve citizens' livelihoods through the creation of employment possibilities. Unemployment is very high, 46\% of Nepal's youth labor force in the age group 20-24 is underutilized (Nepal Labour Force Survey, 2008). Agriculture provides a livelihood for over $80 \%$ of the population and over $85 \%$ of the population lives in rural areas, where harvesting of natural fabrics is significant.

Craftsmanship of textiles and fabrics is deeply rooted in Nepali society, which passes the knowledge from generation to generation, in order to keep remembered traditional technics of handwork. Existence and quality of the life of artisans is dependent on market trends and fast changing customer needs, to which it is not always easy to keep up. To support this important part of Nepali heritage, many organizations have arisen, and craftsmanship gained a place in academic education. When considering any activity related to it, this specific network must be noticed and incorporated into plans. Figure 1 presents a framework for recognizing local stakeholders. A stakeholder is understood here according to Freeman's definition (1984) as "any group or individual who can affect or is affected by the achievement of the organization objectives". This means that any market activity involving craftsmanship has or may have a certain level of relationship to groups of actors listed below. 
In the bottom part of stakeholder map appear actors who bear the direct consequence of the manual production of textiles. They are mostly professionals, like tailors or weavers, but also farmers cultivating a plant, from which the fibers are obtained, as well as processors who prepare a thread, by winding it on a foot-driven reel. The "environment" category (which is related to livelihood and market operation (Haigh \& Griffiths, 2009)), includes natural resources, used for fabric production, and environmental degradation, like pollution, caused by the production. Quality of life of the community of people (e.g. those who take water in the vicinity of dye works or families of craftspeople) depends on the fabric production. They are considered to be stakeholders, whose rights are crucial for any socially responsible initiative.

Figure 1. Stakeholder map

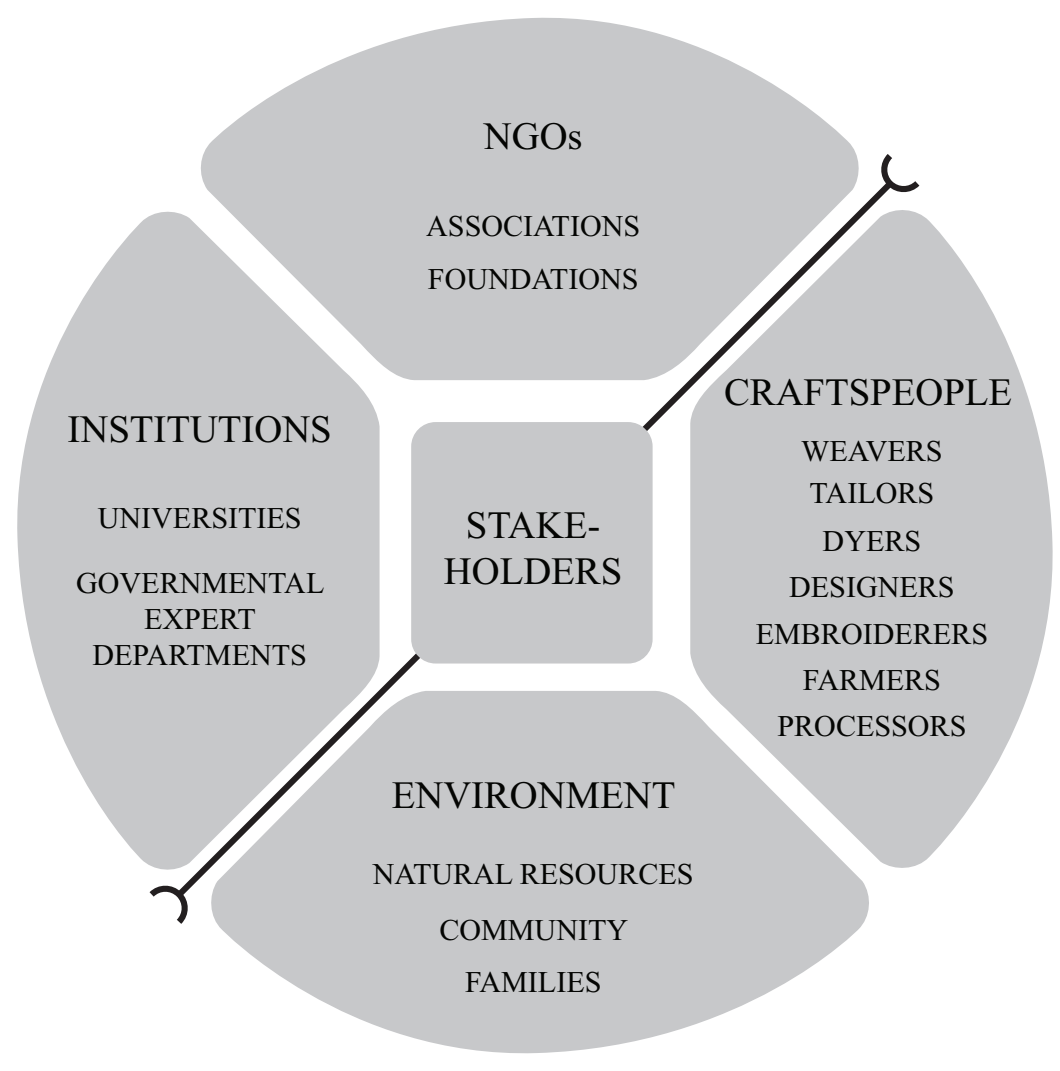

On the other side there groups of local experts, institutional resources and organizations influencing the craft textiles industry, e.g. associations connecting small producers, stimulating their development and providing access to income. This also includes local researchers and knowledge centers that hold valuable information. Such a division covers most of the groups dealing with craftsmanship and became a starting base for planning interviews and observations made for the purpose of this research during the cognitive excursion.

\section{COGNITIVE EXCURSION SUMMARY}

The cognitive excursion to Nepal took place in order to investigate the local textiles industry and recognize the potential for social innovativeness in the field of craftsmanship. In order to achieve it, participants followed a value chain of the fabric's manufacturing and investigated the production process with its ecological and social consequences, but also the potential for responsible design. Special attention was given to a cultural and structural context, in order to recognize the level of 
social awareness, activism, and the ability to accommodate new ideas, as well to find out about structural supportiveness for social innovation.

The team was created out of students and academics of industrial design and management, altogether 6 people. Students, who were gathering material for their final thesis projects, played the role of designers - explorers, equipped with postcolonial theory, cameras and notebooks filled with everyday reflections. They were searching not only for the inspiration, but also for the social consequences of their design. The journey took 16 days and was dedicated to gain an overall view of the textiles industry and to understand the role that craftsmanship plays in it. Moreover, to answer the question - what are the conditions for innovativeness in the field? The table below includes all the visited places, sorted by the type of their activity.

Table 1. Objects of field research

\begin{tabular}{|c|c|c|c|c|c|c|c|c|c|}
\hline \multicolumn{2}{|c|}{ Fabrics and textiles } & \multirow{2}{*}{\multicolumn{2}{|c|}{$\begin{array}{ll} & \text { Dye houses } \\
8 & \begin{array}{l}\text { Dye house1, } \\
\text { screen printing, } \\
\text { embroidery }\end{array}\end{array}$}} & \multirow{2}{*}{\multicolumn{2}{|c|}{$\begin{array}{ll}\text { Education center } \\
11 \quad \text { Kathmandu } \\
\text { University of } \\
\text { Arts KUART }\end{array}$}} & \multicolumn{2}{|c|}{ Shoe manufactures } & \multicolumn{2}{|c|}{$\begin{array}{c}\text { Non-governmental } \\
\text { organizations }\end{array}$} \\
\hline 1 & $\begin{array}{l}\text { Nepal Apparels } \\
\text { Natural Fibers } \\
\text { weaving house }\end{array}$ & & & & & 12 & $\begin{array}{l}\text { Handmade shoe } \\
\text { house }\end{array}$ & 15 & Sabah Nepal \\
\hline 2 & NANF tailoring & 9 & Dye house 2 & & & 13 & $\begin{array}{l}\text { Handmade shoe } \\
\text { house }\end{array}$ & 16 & $\begin{array}{l}\text { Conscious } \\
\text { Impact }\end{array}$ \\
\hline 3 & $\begin{array}{l}\text { Sabah } \\
\text { manufacture }\end{array}$ & 10 & $\begin{array}{l}\text { Automatic dye } \\
\text { house }\end{array}$ & & & & $\begin{array}{l}\text { Handmade shoe } \\
\text { house }\end{array}$ & 17 & Mahaguthi \\
\hline 4 & $\begin{array}{l}\text { Kushma } \\
\text { weaving house }\end{array}$ & & & & & & & 18 & FNCSI \\
\hline 5 & $\begin{array}{l}\text { Kushma home } \\
\text { based weaving } \\
\text { house }\end{array}$ & & & & & & & & \\
\hline 6 & $\begin{array}{l}\text { Nitya Traditional } \\
\text { Tex }\end{array}$ & & & & & & & & \\
\hline 7 & $\begin{array}{l}\text { Wool electric } \\
\text { manufacture }\end{array}$ & & & & & & & & \\
\hline
\end{tabular}

3-16 November 2017.

The program was made in order to meet actors affected by the textiles industry and organizations supporting them or interacting with them. Below a brief explanation:

1. The category "Fabrics" includes: handloom, sewing, embroidery and screen printing workshops

2. Dye houses - where fabrics are dyed;

3. Sabah Nepal - Cooperative representing home-based workers;

4. FNCSI - Association uniting small and cottage industry;

5. Mahaguti Foundation - supporting artisanship;

6. University of Art and Design - source of local design knowledge

Observations were made in 7 manufactures related to weaving fabrics (mostly handcrafts, several equipped with electric machines), 3 footwear manufactures, 3 dyes workshops, embroidery, screen printing and tailoring workshops. Interviews in the form of informal conversations were conducted with farmers, processors and craftsmen employed and self-employed, one business owner, members of non-profit organizations and academics from a local school of design. The variety of visited 
places gave a quite wide view on textiles production possibilities and the overall condition of the industry. It must be noticed, that the majority of the workshops and manufactures were located near the cities, in the most developed regions, around Kathmandu Valley (distance up to $30 \mathrm{~km}$ ), in Pokhara and in Kushma, which is a distanced of $60 \mathrm{~km}$ to the city.

During the journey, there was a smartphone map application in use, which allowed to mark visited places and to attach basic data about them. A detailed photographic documentation has been made, which later was organized by design students and matched with locations, notes and swatches of materials. They were encouraged to recognize available technologies, production parameters, capacity, working conditions, to spot ecological threats and to be sensitive to local culture and tradition. Three workshops were held for the participants of the excursion, dedicated to summarizing and briefly concluding the recently acquired knowledge. The team got involved in so-called "ecoideation" in order to generate ideas helpful to reduce the negative impact of the product (Bocken, Rana, \& Short, 2015). Brainstorming was focused on identifying environmental and social issues related to the textile industry of Nepal. It defined some of the assumptions for product design workshops, during which it was decided for example to use only natural color fabrics in order to minimize the river's pollution and expose a natural beauty of the fabric. After returning to the country, students created products and services, which consider minimizing the environmental effect and maximizing the benefit of local society.

\section{ANALYSIS AND CONCLUSIONS}

The field research, supported with a literature review, brought some findings worth deepening about the current situation of the craftsman society. Below is presented a responsible SWOT analysis of the handloom and handcrafted textiles industry, which includes information related to social and environmental issues. The analysis can be perceived through not only a business perspective, but also as an insight for strategic planning of social innovativeness within the field of craftsmanship.

Table 2. SWOT analysis

\begin{tabular}{|c|c|c|c|}
\hline Strengths & Weaknesses & Opportunities & Threats \\
\hline $\begin{array}{l}\text { Variety of traditional } \\
\text { textiles products }\end{array}$ & Pollution from dye houses & $\begin{array}{l}\text { Rising demand for } \\
\text { handcrafted and fair trade } \\
\text { products in developed } \\
\text { countries }\end{array}$ & $\begin{array}{l}\text { Loss of traditional patterns } \\
\text { and cultural identity }\end{array}$ \\
\hline Uniqueness of handicrafts & $\begin{array}{l}\text { Pollution from processing } \\
\text { fibers }\end{array}$ & $\begin{array}{l}\text { E-commerce as a channel } \\
\text { of sales }\end{array}$ & Logistics \\
\hline Developed retail structure & Lack of modern technology & $\begin{array}{l}\text { Space for collaboration } \\
\text { with world fashion and } \\
\text { design. Meeting global } \\
\text { requirements }\end{array}$ & $\begin{array}{l}\text { Disappearance of craft } \\
\text { practice }\end{array}$ \\
\hline $\begin{array}{l}\text { Variety of NGOs supporting } \\
\text { the industry }\end{array}$ & $\begin{array}{l}\text { Sex discrimination on } \\
\text { managerial levels }\end{array}$ & Product design & $\begin{array}{l}\text { Inadequate quality of } \\
\text { products }\end{array}$ \\
\hline Use of local resources & $\begin{array}{l}\text { Limited access to skills } \\
\text { training }\end{array}$ & $\begin{array}{l}\text { Low cost technological } \\
\text { improvements }\end{array}$ & $\begin{array}{l}\text { Competition from } \\
\text { neighboring countries like } \\
\text { India and China }\end{array}$ \\
\hline $\begin{array}{l}\text { Inclusion of home-based } \\
\text { workers, women and } \\
\text { marginalized groups }\end{array}$ & Poor infrastructure & Employment in rural areas & $\begin{array}{l}\text { Unstable, protectionist } \\
\text { tax policy of developed } \\
\text { countries }\end{array}$ \\
\hline
\end{tabular}


Table 2. (cont.)

\begin{tabular}{|c|c|c|c|}
\hline Strengths & Weaknesses & Opportunities & Threats \\
\hline $\begin{array}{l}\text { Inexpensive technology and } \\
\text { innovation }\end{array}$ & Exploitation by middleman & $\begin{array}{l}\text { Scaling the impact of local } \\
\text { NGOs }\end{array}$ & Dependency on export \\
\hline $\begin{array}{l}\text { Social acceptance for } \\
\text { women and low casts in } \\
\text { textiles industry }\end{array}$ & Little ecological awareness & $\begin{array}{l}\text { Popularization of renewable } \\
\text { energy and sustainable } \\
\text { technology of fabric's } \\
\text { production }\end{array}$ & Export restrictions \\
\hline $\begin{array}{l}\text { Openness for foreign } \\
\text { collaboration }\end{array}$ & $\begin{array}{l}\text { Communication and } \\
\text { marketing skills }\end{array}$ & Niche B2B market & \\
\hline
\end{tabular}

The textiles craftsmanship in Nepal creates a range of opportunities for social impact within the frameworks of inclusive trade, employment and self employment, social and gender equality, technology development and implementation, entrepreneurial and professional education, as well all the innovations related to environment protection. Local producers and traders are still somewhat connected with the world market, however retail structures are well developed and there exists a supportive network of non-governmental organizations, as well as an enthusiastic approach to new ideas. Collaboration between global fashion, design and craftsmanship in a developing economy is beneficial for both sides. Uncertainty however appears on a few levels: standards of communication, reliability of product quality, market suitability considering the offer for the EU and US and access to modern technological advancements, which all together decide on the competitiveness of craftsmanship in comparison to industrial textiles producers. Product development is an opportunity for handcrafted products to meet the needs of global markets. In addition, it opens the space for creative innovativeness and improvements on both social and commercial levels. At the same time, handmade is considered to be luxurious and attractive, which makes the textile craftsmanship still a promising field.

Tradition of textiles and fabrics in Nepal has a long history and the assortment is wide - starting from raw, strong materials (e.g. made of hemp), ending on labor-intensive pattern Dhaka, which is used for soft clothing for festive occasions. The majority of produced fabrics is made of natural fibers. Hemp and Himalayan nettle (allo) are locally resourced, which grow widely in high altitudes. Unfortunately available basic technology is not sufficient to produce thin threads, which makes the offer less competitive, in comparison to China or India.

The value chain of the fabric's production is long and includes many middlemen, which can be a source of exploitation and offers little control over the producer's income. Usually village level traders, who buy the harvested plant from village collectors, or spools of thread from thread makers, have no access to national and international level manufacturers, nor to consumers. This is due to factors like poor accessibility and limited livelihood opportunities (Adhikari, Shrestha, Dorji, Lemke \& Subedee, 2018). Local NGOs connect craftsmen and farmers to the market in order to stabilize their profits and exclude the exploitive factor. Craftsmanship is a source of income to a significant amount of people from developing countries. According to a capabilities approach, society can only evolve when the potential of all the people is released and everyone has a freedom to decide consciously about his or her own future (Sen, 2003). The inclusive value chain is a program which applies Sen's theory into practice. Nepal is a society of a caste system, which was adapted from Hindus immigrants arriving from India since the Muslim invasion in the XIV century. To this day the system is a source of inequalities inherited from generation to generation. Traditionally, castes are associated with specific occupations and economical statuses - Brahman and Chhetri are most privileged and born to participate in politics, administration and the military. On the contrary, there 
are occupational castes (tailors, weavers, shoemakers, blacksmiths, etc.) and Dalit (untouchables), who receive lower income, worse access to education and less of social privileges (Dor, 1967). However development and an open market have brought new possibilities of income generation and mobility between occupations, strengthened by a better access to education (Hamid, 2018).

While the textiles industry became a way to social promotion through entrepreneurship, this is however still not available to everyone. Reality puts additional limitations, like poor or no secure infrastructure, limited access to communication technology and discrimination within the community. Those issues are being tackled by non-profit organizations supporting fair trade and craftsmanship, which reach communities marginalized because of their place of residence or social status. Years of experience in creating social impact made local organizations a repository of knowledge and the third sector in Nepal - very well developed. There are over 40 thousand NGOs in existence in Nepal (Social Welfare Council, 2014). A perfect example to analyze is an innovative program implemented by the Business Association of Home Based Workers (SABAH) in Naugat, a mountain region in fair the far west of Nepal. Through an establishment of community owned enterprise producing local resource-based textiles - the traditional allo (nettle) - organizations tended to bring new economical possibilities to the region. The basic assumption was equal accessibility for everyone, regardless affiliation to social caste or gender. In the past, access to the allo business was often denied to women, whose knowledge and potential was underestimated. To avoid the issue this time around, the community owned an enterprise established for a new, high quality nettle production entirely owned by women. As a result, women got empowered, improved their skills and gained independence. The whole region benefited significantly from this shift - many new small businesses have arisen, technology has improved, and pollution decreased (Adhikari, Shrestha, Dorji, Lemke $\&$ Subedee, 2018). Textiles production is a domain in which the activity of women and other marginalized groups is socially accepted, making it a relatively safe tool of empowerment.

In the Nepali handmade industry one might observe the phenomena of negating one's own culture - imported products are expected to be better than the native ones. During the observations in one of the workshops, there a label "made in England, Fabrique in China" found, even though the whole manual work was done in Nepal. The owner, when asked, has explained, that it is because retailers value less products made in Nepal. This is a popular approach in the times of cosmopolitan trends, the global village and the need to belong to a dominant culture. An interesting point of view shows a Hindu sociologist, Bhabha, H. K., 2004, studying western culture, who feels that her early worldview was dominated by the trend of post-colonial countries, widely accepted adoration for foreign culture, art and literature and a devaluation of native treasures. When working with craftsmen, it is important to support their culture and traditions and to strengthen their sense of worth and pride. International collaboration can be beneficial for awareness of identity, as „Cultures recognize themselves through their projections of 'otherness', the dissidence from representatives of different cultures" (Bhabha, 2004). The problematic is a lack of acceptance from outside or devaluation of traditional products. The import of mass-produced goods from giant neighbors, such as China and India, negatively affects craftsmanship. This is the case for as long as they are striving to be market competitors, as opposed to being alternatives.

One of the biggest threats for the craftsmanship practice is the fact of its complete disappearance due to a lack of continuity and loss of skills and knowledge (as it almost happened for example in the UK). A low income, the devaluation of skills as well as a low social status of the profession are factors that decrease the amount of hand wavers, even though many rural regions have no alternative workplaces. Craftsmanship is not only worth protection, but also needs sustainable development in order to empower marginalized groups and regions. As a field of social innovation, it tackles issues of the poorest. It also protects those left behind during the fast industrialization, which typically has grown in most developed regions, while having negatively affected rural areas. 
Textiles production causes environmental pollution and there is a need for technological modernization in a sustainable spirit - sewers, solar energy, ecological stoves, recycling. During the visits to the dye houses, the problem of environmental pollution was observed - chemical dyes, together with water, are purred straight to the rivers near which the dye workshops are located. The second problem is the burning of waste to warm the water - wood or coal are scarce products, it is common to make a fire with available waste, including plastic. Combustion points were located in the immediate vicinity of residential houses, exposing neighbors to toxic smoke. Naturally colored fabrics are a less toxic, however slightly cheaper artificial dyes, in bright colors, imported from China and India, are more attractive to customers and their choice defines the supply. Researchers have noticed another issue - the process of fibers extraction involves harmful substances, which might be easily replaced - "Use of ash in place of caustic soda reduced negative health impacts like allergies, coughing, and gastritis and was more environmentally friendly" - which is an example of low-cost, locally available, innovative improvement (Adhikari, Shrestha, Dorji, Lemke, \& Subedee, 2018). Simply by skill training, local NGOs bring change and development to the rural industry. The process of yarn harvesting and processing is very traditional, but ineffective, and not practiced anymore by craftsmen from more developed regions who have access to modern technologies (Subedee, Chaudhary, Uprety, \& Dorji, 2018). At the same time, when considering the import of technology, there appears another problem, which should be noticed - building dependencies between the technology provider and its users. However, in an emerging economy, low-cost innovations contribute strongly to a sustainable development (GIZ, 2013). Already in the 60's, the South-African designer Selby Mvusi stressed that the low-income societies must have access to technology (Magaziner, 2018). There is a need for more responsible and ecological craftsmanship powered by the achievements of modern knowledge.

Due to transformative globalization theory, development through fair trade, empowerment and access to technology, is most beneficial and leads to independent and sustainable growth. Local organizations supporting craftsmanship emphasize the importance of connecting the private sector with rural communities. Fair trade entities, sensitive to social issues, are desirable partners of projects for socio-economic development. International collaboration can significantly support local activities and „local ownership” (Chandra, 2018). It is a way to scale the impact of existing initiatives, which have a knowhow and experience in causing social change. Leverage of existing resources is most beneficial and suggested by researchers.

For the future research, the author wishes to work on the above issues on participatory bases, with involvement of local stakeholders, in order to elaborate frameworks for international fair trade, which will be more accessible for responsible entrepreneurs on the one hand, and more inclusive for marginalized producers on the other.

Special thanks to dr Anna Szwaja, dr Andrzej Śmiałek and dr Krzysztof Bogomaz from WFP Krakow, for participation in the cognitive excursion and working with their students on a thesis related to sustainable design in Nepal.

\section{Literature}

Adhikari, L., Shrestha, A. J., Dorji, T., Lemke, E., \& Subedee, B. R. (2018). Transforming the Lives of Mountain Women Through the Himalayan Nettle Value Chain: A Case Study from Darchula, Far West Nepal. Mountain Research and Development, 38(1), 4-13. https://doi.org/10.1659/MRD-JOURNAL-D-17-00074.1

Audebrand, L. K. \& Pauchant, T. C. J. (2009). Can the Fair Trade Movement Enrich Traditional Business Ethics? A Historical Study of Its Founders in Mexico. Netherlands: Springer, 87.

Bhabha, H. (2004). The Location of Culture. London, New York: Routledge Classics. 
Bocken N., Fil A., Prabhu J. (2016). Scaling up social businesses in developing markets. Journal of Cleaner Production, 139, 295-308. https://doi.org/10.1016/j.jclepro.2016.08.045

Bocken, N. M. P., Rana, P., \& Short, S. W. (2015). Value mapping for sustainable business thinking. Journal of Industrial and Production Engineering, 32(1), 88-102. https://doi.org/10.1080/21681015.2014.1000399

Bradley, S. W., Mcmullen, J. S., Artz, K., \& Simiyu, E. M. (2012). Capital is not enough: Innovation in developing economies. Journal of Management Studies, 49(4), 684-717.

Brown, T., Wyatt, J. (2010) Design thinking for social innovation. Stanford Social Innovation Review. Development Outreach, 12(1), 29-43. doi.org/10.1596/1020-797X_12_1_29

Chandra, Y. (2017). Social entrepreneurship as emancipatory work. Journal of Business Venturing, vol. 32(6), 657-673. https://doi.org/10.1016/j.jbusvent.2017.08.004

Chandra, Y. (2018). New narratives of development work? Making sense of social entrepreneurs development narratives across time and economies. World Development, 107, 306-326. https://doi.org/10.1016/j.worlddev.2018.02.033

Chiappero-Martinetti, E., Ziegler, R., Budd, C. H., Social Innovation and the Capability Approach-Introduction to the Special Issue, Journal of Human Development and Capabilities, 18(2), 141-147.

Dawson, P., \& Daniel, L. (2010). Understanding social innovation: a provisional framework. International Journal of Technology Management, 51(1). https://doi.org/10.1504/IJTM.2010.033125

Dey, P., \& Steyaert, C. (2016). Rethinking the Space of Ethics in Social Entrepreneurship: Power, Subjectivity, and Practices of Freedom. Journal of Business Ethics, 133(4), 627-641. https://doi.org/10.1007/s10551-014-2450-y

Dor, B., B. (1967). People of Nepal. Kathmandu: Ratna Pustak Bhandar.

Elia, G., \& Margherita, A. (2018). Can we solve wicked problems? A conceptual framework and a collective intelligence system to support problem analysis and solution design for complex social issues. Technological Forecasting and Social Change, 133(October 2017), 279-286. https://doi.org/10.1016/j.techfore.2018.03.010

Fair Wear Foudation, Country Study Nepal, June 2013.

Fontaine, Ch., Haarman, A., Schmid, S., (2006). The stakeholder theory. https://pdfs.semanticscholar.org/606a /828294dafd62aeda92a77bd7e5d0a39af56f.pdf

Freeman, R.E (1984). Strategic Management: A stakeholder Approach. Journal of Management Studies, 29(2) $10.1017 /$ CBO9781139192675

GIZ [German Corporation for International Cooperation]. 2013. Value Chain Development by the Private Sector in Africa: Lessons Learnt and Guidance Notes. Germany. http://www.plugintheworld.com/mobisol/wp-content/ uploads/2014/01/Value-chain-development-by-the-private-sector-in-Africa. pdf; accessed in September 2018.

Haigh, N. and Griffiths, A. (2009), The natural environment as a primary stakeholder: The case of climate change. Business Strategy and the Environment, 18(6), 347-359.

Hamid A., Changing Pattern of Relationships - Caste Vs Occupations. The Thumb Print - A magazine from the East. http://www.thethumbprintmag.com/changing-pattern-of-relationships-between-caste-and-occupations/ Accessed on August 2018.

Hanington, B., Martin B. (2012). Universal Methods of Design: 100 Ways to Research Complex Problems. Beverly, MA: Rockport Publishers.

Hillgren, P. A., Seravalli, A., \& Emilson, A. (2011). Prototyping and infrastructuring in design for social innovation. CoDesign, 7(3-4), 169-183, https://doi.org/10.1080/15710882.2011.630474

Mair, J., \& Martí, I. (2006). Social entrepreneurship research: A source of explanation, prediction, and delight. Journal of World Business, 41(1), 36-44, https://doi.org/10.1016/j.jwb.2005.09.002

Mills, D. (2000). Introduction to Action Research: Social Research for Social Change, American Anthropologist, 102(3). doi: 10.1525/aa.2000.102.3.659

Mormina, M. (2018). Science, Technology and Innovation as Social Goods for Development: Rethinking Research Capacity Building from Sen's Capabilities Approach. Science and Engineering Ethics. https://doi. org/10.1007/s11948-018-0037-1

Magaziner, D. (2018). The Foundation: Design, Time, and Possibility in 1960s Nairobi. Comparative Studies in Society and History, 60(3), 599-628, doi:10.1017/S0010417518000208

Nepal Labour Force Survey NLFS. (2008). Central Bureau of Statistics, http://www.ilo.org/surveydata/index. $\mathrm{php} / \mathrm{catalog} / 1357 /$ study-description

Papanek, V. (2012). Dizanj dla realnego świata. Łódź: Recto Verso.

Perrini, F., Vurro, C., \& Costanzo, L. A. (2010). A process-based view of social entrepreneurship: From opportunity identification to scaling-up social change in the case of San Patrignano. Entrepreneurship and Regional Development, 22(6), 515-534. https://doi.org/10.1080/08985626.2010.488402

Reijonen, E. K. (2012). Enhancing the capabilities of small producers in developing countries to meet global challenges: an investigation into the contribution of international craft development initiatives. Open Access Institutional Repository by Robert Gordon University, https://openair.rgu.ac.uk/handle/10059/573 
Santos, F. M. (2012). A Positive Theory of Social Entrepreneurship. Journal of Business Ethics, 111(3), 335-351. https://doi.org/10.1007/s10551-012-1413-4

Sapir, E. (1924). Culture, Genuine and Spurious. American Journal of Sociology, 29(4), 401-429.

Sapkota, Ch. (2010). Demise of Garment Sector, Republica.

Selloni, D., Corubolo, M. (2017). Design for Social Enterprises: How Design Thinking Can Support Social Innovation within Social Enterprises. Design Journal, 20(6): 775-794. https://doi.org/10.1080/14606925.2 017.1372931

Sen, A. (2003). Development as capability expansion, Readings in Human Development, New Delhi and New York, Oxford University Press, 41-58.

Social Welfare Council (SWC). (2014).

Starnawska, M. (2016). Identyfikowanie zasobów i lokalnych potrzeb w preprzedsiębiorczej fazie inicjatyw spotecznych. Animacja społeczna - praca nad zmiana. Gdańsk-Gdynia-Sopot: MMediterranean Politics, 26-37.

Stephan, U., Patterson, M., Kelly, C., \& Mair, J. (2016). Organizations Driving Positive Social Change: A Review and an Integrative Framework of Change Processes. Journal of Management, 42(5), 1250-1281. https:// doi.org/10.1177/0149206316633268

Stott, N., \& Tracey, P. (2018). Organizing and innovating in poor places. Innovation: Management, Policy and Practice, 20(1), 1-17.

Subedee, B. R., Chaudhary, R. P., Uprety, Y., \& Dorji, T. (2018). Socio-ecological perspectives of Himalayan Giant Nettle (Girardinia diversifolia (Link) Friis) in Nepal. Journal of Natural Fibers, 00(00), 1-9. https:// doi.org/10.1080/15440478.2018.1458684

Trzcieniecki J. (1979), Projektowanie systemów zarzadzania, Warszawa:PWN.

WITS -https://wits.worldbank.org/CountryProfile/en/Country/NPL/Year/2015/Summary

Young, W., \& Tilley, F. (2006). Can businesses move beyond efficiency? The shift toward effectiveness and equity in the corporate sustainability debate. Business Strategy and the Environment, 15(6), 402-415. https:// doi.org/10.1002/bse. 510

Ziegler, R., Schulz, S., Richter, L., \& Schreck, M. (2014). Following Gandhi: Social entrepreneurship as a non-violent way of communicating sustainability challenges. Sustainability (Switzerland), 6(2), 1018-1036. 